\title{
Commentary
}

\section{Reply: Trauma, citizenship and ethnographic responsibility}

\author{
Karen E. Till* \\ National University of Ireland Maynooth, Department of Geography, Rhetoric House, Room 23C, Maynooth, County Kildare, Ireland
}

Keywords:

Citizenship

Trauma

Ethnography

Wounded cities

In response to the generous comments by Rob Shields, Jeffrey Garmany and Kevin Ward, I would like to raise three interrelated themes: trauma, citizenship, and ethnographic responsibility.

Rob Shields eloquently traces the longer-standing histories of trauma and memory that offer a sophistication and richness lacking in many interdisciplinary debates. With the rise of U.S.-based popularized trauma studies in the 1980s and 1990s, the technical concept "trauma" began to be used problematically to describe the outcomes of attenuated violence and suffering in social settings, and to prescribe collective remedies. In the first instance, research findings from one context - in particular studies of Holocaust and child sexual abuse survivors - were generalized to interpret different social and individual experiences through a simplistic casual framework whereby "a given event (a catastrophe) produces a given effect" (trauma) (Hodgkin \& Radstone, 2003: 97). Yet Freudian psychoanalytic theory defines trauma as a product of the inner workings of the mind not as resulting directly from an event. As Mieke Bal (1999) describes, traumatic memories resist integration and cannot become narratives, "either because the traumatizing events are mechanically reenacted as drama rather than synthetically narrated by the memorizing agent who 'masters' them, or because they remain 'outside' the subject" (p. viii). Trauma does not occur from an event or occurrence that caused pain or suffering per se, but from an individual's inability to give the past some sort of story.

In the second instance, when translating the psychoanalytic model of individual trauma to a social situation, the Western idea of "therapy" has been exported. Collective forms of "talking cures" to "heal trauma," however, may result in other forms of violence. As Christopher Colvin (2003) has argued in the case of post-apartheid South Africa, a range of more appropriate testimonial cultures existed for communities than the dominant post-Truth and Reconciliations Commission (TRC) "therapeutic form of public memory." Colvin argues that the Khulumani Victim Support Group developed narratives "centred on a long-

\footnotetext{
* Tel.: +353 831114265; fax: +35317083573.

E-mail address: karen.till@nuim.ie.
}

suffering, but not yet recovered victim" (p. 165). This individual is not a heroic figure who forgives and thus moves society toward reconciliation; the Khulumani understand healing in terms of owning the narration and transmission of individual memories, and in terms of tangible improvements in the quality of their lives. For Khulumani, it is an illusion to talk about the past as the space-time of racism and state oppression, and the present as a "redeemed" space-time of freedom and democracy. They understand the present as "a not yet finished phase of history's unfolding" (p. 166).

Shields' discussion of trauma as both stress and wound, and as involving "the actualization of unexpected aspects and capacities of places, people and communities," also is sensitive to the multiple temporalities and unfoldings of presences in pasts and possible futures. In his more expansive use of the term trauma, Shields highlights a possible ethics of memory-work and care through embodied rituals and shared experience. When considered in terms of a "flexing, cultural topology," care as a social and embodied form of placebuilding is what Shields describes as an "aesthesis" that "walks with us" and yet is also socially shared. As such, he argues that we can consider a place-based ethics of care and memory-work as embedded practices of "sense-making" that might lead to "solidarity." Such practices are not moralistic but tied to an idea of inhabitant-citizens defining practices of social responsibility through place-building.

As Jeff Garmany describes, distinctive forms of wounding occur in many parts of the world, when residents "become disconnected from the public spaces they once frequented," when the "spatial connectivities produced by local affinity groups and assemblages of neighborhood cohesion become unraveled," or when it becomes too dangerous to traverse routine networks and pathways. In learning of his ethnographic work in Pirambu, Brazil, I was reminded of El Cartucho, Colombia, where some residents were refugees from places wounded through paramilitary and drug cartel violence, and then became again displaced with the building of the Third Millennium Park. Garmany rightfully raises concerns about the discourses of citizenship and rights in these contexts, in particular when individuals are defined according to their subject position relative to the apparatus of the state. As Foucault (1995 
[1975]) reminds, the political dream of a disciplined society or bodypolitic always renders individuals - and I would add places - as objects through spatial partitioning and surveillance. Indeed, when citizenship itself is used as a technology, "citizens" may ask the state to use paternalistic pastoral care, including through primitive forms of power and violence (walls, brute force, imprisonment), against "noncitizens" who supposedly threaten the freedom of citizens.

As Garmany recognizes, I am not advocating a continuation of rights and citizenship according to such legal and disciplinary mechanisms that render inhabitants as populations. At the same time, as I have indicated above, I am not yet prepared to give up on the idea that social policies and forms of belonging might be based on both intergenerational responsibilities and rights, and place-based ethical forms of care. As Kevin Ward notes, care here includes the right to repair, the right to memory-work, the right to leave open the possibilities of the past and future. Further, I believe it is worthwhile to explore the possibilities of a citizen-witness-care-giver according to a civil contract (after Azoulay, 2008), rather than as always already defined through differentiated legal forms of state citizenship.

While I agree with Ward that capitalism plays a role in the ways in which cities are wounded, the economic imperative of the capitalist land market does not explain extreme forms of racism and fears of the Other. To analyze wounded cities, places, and inhabitants primarily according to the ordinary processes of capitalist urbanization and their concomitant violences would be a mistake. Creative destruction as a concept cannot adequately address the material, emotional, intergenerational, and place-based forms of state-perpetrated violence with which I am principally concerned. For example, the destruction of thousands of African American communities across the U.S. may have appealed to economic need in the rhetoric of "slum clearance" when federal and local government institutions funded "urban renewal" programs that laid waste to neighborhoods. Displaced residents were not compensated, nor were they provided with alternative housing; if compensation was later provided it would not be able to attend to the social, personal, material, and neighborhood damage created once historic communities were destroyed. The cities, moreover, were treated to further rounds of razing from which some have never recovered. Even after extensive clearance, new development never arrived.

This was not creative destruction. This is closer to what Azoulay (2011) describes as "infra-destructure." In her work about the Israeli-Palestinian war, Azoulay refers to "regime-made disasters" to analyze the more than forty years of Palestinian occupation by Israeli authorities. She uses the concept "infra-destructure" to refer to the slow, systematic removal of hospitals, schools, housing, public spaces and other forms of social infrastructure. This form of damage and disaster has affected not only the Palestinians, but also Israelis who, over generations, have come to see Palestinians as always associated with ruins, war, and danger, and even as not deserving the right of political protest during the so-called "Arab Spring." Azoulay's concept "infra-destructure," with Fullilove's concept of "root shock," more accurately describe in my opinion the multi-generational negative effects of wounding than does the master narrative of creative destruction. The map of empty lots in Gainsboro does not demonstrate the slow removal of homes, community centers, or social networks and personal mazeways. Nor does it indicate the decades of institutional, state, and everyday racism in these assaults upon inner city neighborhoods and their residents, or the fears that people have living in and/or visiting these neighborhoods. More than forty years later, many of these razed spaces in neighborhoods from Gainsboro to Seward Park in the Lower East Side of New York remain off limits to local communities, often fenced off with no housing or infrastructure, held in state hands or those of absentee landlords. Roanoke remains one of the most segregated cities of its size in the US. It is and will be very difficult to repair or create new healthy social ecologies of place in this wounded city unless we begin to pay attention to the many levels of past and ongoing violences.

By way of conclusion, I wish to discuss ethnographic responsibility to respond to Ward's important comments regarding methodology. Ethnography - and here I do not mean simply interviews - is an iterative research practice in which the researcher seeks to understand rather than to predict. It often unfolds through mistakes and unexpected insights. I did not begin this study with a specific agenda to reconceptualize urban politics, nor did I look for case studies to illustrate my concept of wounded cities. The inhabitants, artists, and places I have studied have inspired me to rethink in fundamental ways how I understand "the city." It was only after numerous extended visits to Cape Town working with the District Six Museum staff that I returned to my (then) home in Minneapolis and learned about the extent of violence that continued to structure the city in which I lived. The extent of racism, violence and invisibility - and my inability to see my own home - deeply unsettled and humbled me. The very grounds of the university upon which I routinely traversed were stolen lands. The airport that I regularly flew into was near what the Dakota peoples call Bdote, the center of creation and the universe. After the wars related to "statehood," hundreds of Dakota men, women, and children were interred in concentration camps on this sacred land. Eighty-eight Dakota leaders were sentenced to hang by President Lincoln. Although Minneapolis has the largest Native American urban population in the U.S. and the state of Minnesota is home to many sovereign nations, these peoples remains spatially, socially, culturally, and economically segregated. Through talking with Mona Smith, a Dakota multi-media artist and educator in Minneapolis, I began to realize how inadequate were existing theories of the city and urban politics for failing to acknowledge these stories, ghosts, ancestral presences, natures, and ongoing violences. I also realized that my attachment to critical theory did not allow me to "hear" the ways that individuals described the places to which they were attached as a kind of meta-subject. I therefore turned to other approaches, including artistic and creative practices, social psychiatry, and postcolonial theory. I began to listen differently to the stories that people shared with me in the cities in which I studied and lived.

The concepts I developed and introduced in a preliminary way in this article are grounded in many years of learning about these cities, and in an ethical responsibility of listening, respecting, and, just maybe, also in giving something back to those who have generously shared their stories and insights with me. I hope that I have done justice to their particular stories and to the larger patterns that emerged as people talked about their attachments to places and cities. Ward's astute questions regarding the particular meanings and contexts of the wounded cities I have selected will have to be, of necessity, delayed for the book so that I can provide the appropriate detail needed. For now, I hope that the concepts I have developed here give a sense of the wisdom of the peoples and places I have worked with and also begin to "speak back" to the inadequacies of existing urban and political theory.

\section{References}

Azoulay, A. (2008). The civil contract of photography. Cambridge, MA: MIT Press.

Azoulay, A. (2011). Infra-destructure. Paper delivered at the injured cities/urban afterlives conference at the center for critical analysis of social difference. New York: Columbia University. October 14

Bal, M. (1999). Introduction. In M. Bal, J. Crewe, \& L. Spitzer (Eds.), Acts of memory: Cultural recall in the present. Hannover, NH: University Press of New England, (pp. vii-xvii).

Colvin, C. (2003). 'Brothers and sisters do not be afraid of me': trauma, history and the therapeutic imagination in the new South Africa. In K. Hodgkin, \& S. Radstone (Eds.), Contested pasts: The politics of memory (pp. 153-167). London: Routledge.

Foucault, M. (1995 [1975]). Discipline and punish: The birth of the prison (2nd ed.). New York: Vintage Books. transl. Alan Sheridan.

Hodgkin, K., \& Radstone, S. (2003). Remembering suffering: trauma and history. In K. Hodgkin, \& S. Radstone (Eds.), Contested pasts: The politics of memory (pp. 97-103). London: Routledge. 